ARQGA/1139

\title{
CAPELLA'S GASTROPLASTY: metabolites and early phase proteins changes in midline and bilateral arciform approaches
}

\author{
Luiz Gonzaga de MOURA Jr. ${ }^{2}$, Sérgio Botelho GUIMARÃES ${ }^{1}$, \\ Heládio Feitosa de CASTRO-FILHO $^{1}$, Heine Ferreira MACHADO ${ }^{1}$, \\ Francisca das Chagas FEIJÓ ${ }^{1}$ and Paulo Roberto Leitão de VASCONCELOS ${ }^{1}$
}

\begin{abstract}
Background - Obesity has adverse health effects. Dietary reeducation does not seem to offer sustained weight loss. For appropriately selected patients, surgery may be beneficial. Aim - To evaluate early postoperative metabolic response to surgery in patients submitted to Capella's gastroplasty using two different surgical approaches to the abdominal cavity. Patients/Method - Twenty patients (9 males and 11 females, aged 21 to 53 years) were randomized prior to submission to either one of the surgical access incisions (bilateral arciform or supra-umbilical midline incisions). Blood samples were collected at the beginning and end of the operation, 12 (T-12 h) and 24 hours (T-24 h) postoperatively. Dieresis and synthesis time, blood loss, planimetry of operative field, operative time, hospital stay, hemoglobin, hematocrit, lymphocytes, potassium, albumin, erythrocyte sedimentation rate, C-reactive protein, glucose, pyruvate, lactate and ketone bodies were analyzed. Results - Dieresis time was significantly decreased when median approach was used. Total operating time, hospital stay, hematocrit, hemoglobin, lymphocyte count, potassium and albumin concentrations were similar in both groups. C-reactive protein (T-12 h), glucose and pyruvate concentrations (T-24 h) increased significantly after completion of surgical procedure. Ketone bodies concentrations were significantly decreased 24 hour following completion of surgical procedure. Conclusion - Capella's gastroplasty induces metabolic and inflammatory changes in blood parameters. There is no evidence of technical superiority of arciform over midline incisions in this study. HEADINGS - Obesity, morbid, surgery. Obesity, morbid, metabolism. Gastroplasty.
\end{abstract}

\section{INTRODUCTION}

Obesity is defined as a condition where the body weight is above normal pattern for height and skeleton frame associated with an excessive ingestion of calories and decreased consumption leading to significant weight gain with adverse health effects and diminished longevity.

Human obesity is accompanied by an outstanding increase of the number of adipocytes. Weight loss may decrease cellular volume; however, cell number remains elevated. Patients who develop early obesity present an increased number of adipose cells when compared to those with late onset of the illness ${ }^{(13)}$.

Adipocytes work together as a single unit in the release of many substances such as leptin, adipsin, angiotensinogen, prostaglandins and tumor necrosis factor (TFN-alpha) among others. Leptin has been acknowledged as an adipocyte-derived signal molecule, able to limit food intake and increase energy expenditure by interacting with specific leptin receptors located in the central nervous system and in peripheral tissues. Leptin concentration in humans is directly proportional to the mass of fatty tissue. There is a clear association between weight loss and decrease of leptin ( $10 \%$ weight loss may occur if leptin concentration drops to $50 \%$ of original values $)^{(5)}$.

Even mild degrees of obesity have adverse health effects and are associated with decreased longevity. There is already considerable evidence of links between increased production of some adipocyte factors and the metabolic and cardiovascular complications of obesity $^{(11)}$. Patients with body mass index exceeding 40 have medically significant obesity and a substantial risk of health hazards with concomitant reduction in life expectancy. Dietary reeducation does not seem to offer sustained weight loss. For appropriately selected patients, surgery may be beneficial ${ }^{(9)}$.

Bariatric surgery seems to be the treatment of choice for well-informed and motivated obese patients with acceptable operative risks, who strongly desire substantial weight loss or who have severe impairments because of their weight ${ }^{(1)}$.

This study aims to evaluate early postoperative metabolic response to surgery and the usefulness of two different surgical approaches (transverse arciform and midline incisions) to the abdominal cavity in morbid obesity patients submitted to Capella's gastroplasty.

\section{PATIENTS AND METHODS}

\section{Patients and study design}

The study population comprised of 20 patients ( 9 men and 11 women aged 21 to 53 years, mean 35.5 years). Written consent was obtained from all patients before the study. The study was conducted in accordance with the Declaration of Helsinki and

\footnotetext{
Department of Surgery and ${ }^{2}$ Post-graduation Program (Stricto sensu), Faculty of Medicine, Federal University of Ceará, Fortaleza, CE, Brazil.

Address for correspondence: Dr. Paulo Roberto Leitão de Vasconcelos - Departamento de Cirurgia - Rua Prof. Costa Mendes, 1608 - 3o andar - $60430-140$ - Fortaleza, CE, Brazil. E-mail: mcirur@npd.ufc.br
} 
Moura Jr LG, Guimarães SB, Castro-Filho HF, Machado HF, Feijó FC, Vasconcelos PRL. Capella's gastroplasty: metabolites and early phase proteins changes in midline and bilatera arciform approaches

was approved by the Ethics on Research Committee of the Federal University of Ceará, Fortaleza, CE, Brazil (Protocol \#128.02).

\section{Patient's randomization}

Patients were randomized prior to submission to either one of the surgical access incisions (transverse arciform or supra-umbilical midline incisions). The first patient was selected by single card drawing and was submitted to standard midline incision. Next patient was submitted to transverse arciform incision. The remaining odd-even patients were allocated in an alternated fashion.

\section{Patient's care}

Preoperative care included complete evaluation of general health by a team of clinical specialists and multiple preoperative exams (upper digestive tract endoscopy, spirometry, gasometry, electrocardiography, abdominal ultrasound sonography and radiological examination of lungs and atlantooccipital articulation). Laboratory exams included complete blood count, coagulogram, blood glucose, urea, creatinine, total proteins and fractions, transaminases, gama-glutamyltransferase, viral markers for hepatitis, anti-HIV test, total bilirrubin and fractions, alkaline phosphatase, total cholesterol and fractions, triglycerides, calcium, potassium and zinc determinations and urinalysis. All surgical procedures were performed by the same operating team (head surgeon, two auxiliary surgeons, a scrub nurse and two anesthesiologists). Postoperative care was carried out by a multidisciplinary team composed of intensive care, cardiology, nutrition, physiotherapy and psychology specialists along with a general care nurse.

\section{METHODS}

All patients were submitted to general inhalatory anesthesia. Preanesthetic medication included lorazepam, ranitidine, cephazoline and fraxiparine. Surgical approach was carried out according to the procedure selected during randomization. All patients were submitted to Capella's gastroplasty (combination of vertical banded gastroplasty and Roux-en-Y gastric bypass) $)^{(3)}$. Blood samples were collected at the beginning and at the end of the surgical procedure (T-0 and T-F, respectively) and 12 and 24 hours later.

The following parameters were considered when comparing incisions: time of dieresis (from skin to parietal peritoneum incisions); time of synthesis (from parietal peritoneum to skin sutures); dry and wet sponge weights for blood loss determinations; planimetry of operative field, length of time required for jejunojejunostomy and making of gastric pouch; visualization of gastroesophageal junction.

\section{Biochemical determinations}

Heparinized blood samples collected for enzymatic determinations were deproteinized in vials containing $\mathrm{HCl}_{4}(10 \%)$ and kept cold until centrifuged. Following neutralization supernatant fractions were used as samples for enzymatic analyses (blood concentrations of glucose, pyruvate, lactate, acetoacetato and 3-hydroxibutirate). Glucose concentrations were measured after SLEIN's ${ }^{(10)}$ method. Pyruvate and acetoacetate concentrations were measured after HOHORST et al. ${ }^{(6)}$ and WILLIAMSON et al. ${ }^{(14)}$ methods. Lactate concentrations were measured after $\mathrm{HOHORST}^{(7)}$ method and $\beta$-hydroxybutirate was measured after WILLIAMSON et al. ${ }^{(14)}$ methods. Additional heparinized blood samples were used for complete blood count, albumin, potassium, sedimentation rate and C-reactive protein (CRP) determinations.

\section{Statistical analyses}

Friedman's and Mann-Whitney statistical tests were used for statistical analyses. Results were expressed as mean \pm SEM. Values of $P<0.05$ were accepted as statistically significant.

\section{RESULTS}

Mean values for time spent on abdominal wall dieresis is shown in Table 1 . There was a significant decrease $(P<0.05)$ in dieresis time when median approach was used. Blood loss was similar in both groups (Table 1). There was no significant statistical difference between groups when comparing surgical exposure area (planimetry), abdominal incision closure time (synthesis), length of time required for jejunojejunostomy or gastric pouch making and visualization of gastroesophageal junction. Total operating time and hospital stay were similar in both groups.

TABLE 1 - Type of incision and time spent on abdominal wall dieresis and blood loss during surgical procedure

\begin{tabular}{lcc}
\hline Type of incision & Time $(\mathrm{min})$ & Blood loss $(\mathrm{mm} 3)$ \\
\hline Midline $(\mathrm{M})$ & $8.4^{*} \pm 1.53$ & $52.5 \pm 1.64$ \\
Arciform $(\mathrm{A})$ & $10.9 \pm 1.44$ & $55.4 \pm 1.72$ \\
\hline
\end{tabular}

* $P<0.05$ compared to $(A)$

Hematocrit (Table 2) and hemoglobin (Table 3) were significantly decreased $(P<0.001) 12$ hours later $(\mathrm{T}-12 \mathrm{~h})$ when compared to $\mathrm{T}-0$ when all cases were included in one large group $(n=20)$ despite of absence of significant differences between groups. The same results were found when comparing lymphocyte count (Table 4).

TABLE 2 - Types of incision and hematocrit values during and after (p.o.) surgical procedure

\begin{tabular}{lcccc}
\hline \multirow{2}{*}{$\begin{array}{l}\text { Type of } \\
\text { incision }\end{array}$} & \multicolumn{4}{c}{ Postoperative time (p.o.) } \\
\cline { 2 - 5 } & T-0 & T-F & T-12 h & T-24 h \\
\hline Midline (M) & $40.18 \pm 1.69$ & $35,44 \pm 1.95$ & $38.04 \pm 1.34$ & $36.74 \pm 1.7$ \\
Arciform (A) & $42.0 \pm 1.27$ & $37.47 \pm 2.87$ & $37.74 \pm 1.14$ & $37.26 \pm 1.4$ \\
Total (M+A) & $41.35 \pm 1.06$ & $36.45 \pm 1.71$ & $37.89 * \pm 0.86$ & $37.0 \pm 1.08$ \\
\hline
\end{tabular}

T-O: beginning of surgical procedure

T-F: end of surgical procedure

T. $P$ h $/ T-24 h .12$ and 24 h p.o.

TABLE 3 - Types of incision and hemoglobin values during and after (p.o.) surgical procedure

\begin{tabular}{lcccc}
\hline \multirow{2}{*}{$\begin{array}{l}\text { Type of } \\
\text { incision }\end{array}$} & \multicolumn{4}{c}{ Postoperative time (p.o.) } \\
\cline { 2 - 5 } & T-0 & T-F & T-12 h & T-24 h \\
\hline Midline (M) & $13.41 \pm 0.44$ & $11.73 \pm 0.99$ & $12.89 \pm 0.41$ & $12.14 \pm 0.53$ \\
Arciform (A) & $14.18 \pm 0.61$ & $12.4 \pm 0.72$ & $12.74 \pm 0.53$ & $12.38 \pm 0.67$ \\
Total $(\mathrm{M}+\mathrm{A})$ & $13.79 \pm 0.38$ & $12.06 \pm 0.6$ & $12.81^{*} \pm 0.33$ & $12.26 \pm 0.42$ \\
\hline $\begin{array}{l}\text { T-0: beginning of surgical procedure } \\
\text { T-F: end of surgical procedure }\end{array}$ & & & \\
T-12 $\mathrm{h} / \mathrm{T}-24 \mathrm{~h}: 12$ and 24 h p.o. \\
* $P<0.001$ when compared to T-0
\end{tabular}

Potassium concentrations were alike in patients submitted to median or arciform incisions. However there was a decrease in kalemia T-24h compared to T-0 when all $(\mathrm{n}=20)$ patients were analyzed together (Table 5).

Blood albumin concentration (Table 6) and sedimentation rate (Table 7) were significantly decreased in T-F compared to T- 0. 
Moura Jr LG, Guimarães SB, Castro-Filho HF, Machado HF, Feijó FC, Vasconcelos PRL. Capella's gastroplasty: metabolites and early phase proteins changes in midline and bilateral arciform approaches

TABLE 4 - Types of incision and lymphocyte count during and after (p.o.) surgical procedure

\begin{tabular}{lcccc}
\hline \multirow{2}{*}{$\begin{array}{l}\text { Type of } \\
\text { incision }\end{array}$} & T-0 & T-F & T-12 h & T-24 h \\
\cline { 2 - 5 } Midline (M) & $2262.8 \pm 189.02$ & $2047.2 \pm 326.49$ & $1373.2 \pm 156.6$ & $1576.7 \pm 111.01$ \\
Arciform (A) & $2592.2 \pm 189.24$ & $1901.5 \pm 214.76$ & $1113.6 \pm 101.52$ & $1567.6 \pm 161.88$ \\
Total (M+A) & $2427.5 \pm 135.54$ & $1974.35 \pm 190.9$ & $1234.4 * \pm 95.58$ & $1572.15 \pm 85.53$ \\
\hline $\begin{array}{l}\text { T-0: beginning of surgical procedure } \\
\text { T-F: end of surgical procedure }\end{array}$ & & & \\
T-12 $\mathrm{h}$ /T-24 h:12 and 24 $\mathrm{h}$ p.o. \\
$* P<0.001$ when compared to T-0
\end{tabular}

TABLE 5 - Types of incision and potassium concentrations during and after (p.o.) surgical procedure

\begin{tabular}{lcccc}
\hline \multirow{2}{*}{$\begin{array}{l}\text { Type of } \\
\text { incision }\end{array}$} & T-0 & T-F & T-12h & T-24h \\
\cline { 2 - 5 } & $4.01 \pm 0.11$ & $3.99 \pm 0.14$ & $3.69 \pm 0.11$ & $3.75 \pm 0.18$ \\
Midline (M) & $3.73 \pm 0.15$ & $3.88 \pm 0.19$ & $3.49 \pm 0.12$ & $3.49 \pm 0.11$ \\
Arciform (A) & $3.87 \pm 0.09$ & $3.94 \pm 0.12$ & $3.59 \pm 0.08$ & $3.62 * \pm 0.11$ \\
Total $(\mathrm{M}+\mathrm{A})$ & &
\end{tabular}

$\mathrm{T}-0$ : beginning of surgical procedure

T-F: end of surgical procedure

$\mathrm{T}-12 \mathrm{~h} / \mathrm{T}-24 \mathrm{~h}: 12$ and $24 \mathrm{~h}$ p.o.

* $P<0.05$ when compared to $\mathrm{T}-\mathrm{O}$

TABLE 6 - Types of incision and albumin concentrations during and after (p.o.) surgical procedure

\begin{tabular}{lcccc}
\hline \multirow{2}{*}{$\begin{array}{l}\text { Type of } \\
\text { incision }\end{array}$} & T-0 & T-F & T-12h & T-24h \\
\cline { 2 - 5 } & $3.77 \pm 0.09$ & $2.83 \pm 0.27$ & $3.14 \pm 0.14$ & $3.14 \pm 0.11$ \\
Midline (M) & $4.11 \pm 0.12$ & $3.00 \pm 0.19$ & $3.15 \pm 0.11$ & $3.26 \pm 0.14$ \\
Arciform (A) & $3.94 \pm 0.08$ & $2.92 * \pm 0.16$ & $3.15 \pm 0.09$ & $3.20 \pm 0.09$ \\
\hline
\end{tabular}

T.0: beginning of surgical procedure

T-F: end of surgical procedure

T. $12 \mathrm{~h} / \mathrm{T}-24 \mathrm{~h}: 12$ and $24 \mathrm{~h}$ p.o.
* $P<0.001$ when compared to T-0

TABLE 7 - Types of incision and erythrocyte sedimentation rate during and after (p.o) surgical procedure

\begin{tabular}{lcccc}
\hline \multirow{2}{*}{$\begin{array}{l}\text { Type of } \\
\text { incision }\end{array}$} & \multicolumn{4}{c}{ Postoperative time } \\
\cline { 2 - 5 } & T-0 & T-F & T-12h & T-24h \\
\hline Midline (M) & $31.70 \pm 7.73$ & $17.80 \pm 4,69$ & $35.60 \pm 7.18$ & $31.70 \pm 6.29$ \\
Arciform (A) & $17.30 \pm 5.03$ & $9.20 \pm 2.25$ & $17.10 \pm 4.86$ & $21.90 \pm 5.44$ \\
Total $(\mathrm{M}+\mathrm{A})$ & $24.50 \pm 4.78$ & $13.50^{*} \pm 2.72$ & $26.35 \pm 4.72$ & $26.80 \pm 4.20$ \\
\hline
\end{tabular}

T-O: beginning of surgical procedure

T-F: end of surgical procedure

$T-12 h / T-24 h: 12$ and $24 h$ P.O.
$* P<0.001$ when compared to $T-0$

CRP concentrations increased significantly 24 hours after completion of surgical procedure (Table 8).

TABLE 8 - Types of incision and C-reactive protein concentrations during and after (p.o) surgical procedure

\begin{tabular}{lcccc}
\hline \multirow{2}{*}{$\begin{array}{l}\text { Type of } \\
\text { incision }\end{array}$} & \multicolumn{4}{c}{ Postoperative time } \\
\cline { 2 - 5 } & T- 0 & T-F & T-12h & T-24h \\
\hline Midline (M) & $2.26 \pm 0.83$ & $1.42 \pm 0.51$ & $3.72 \pm 0.92$ & $10.95 \pm 1.07$ \\
Arciform (A) & $0.81 \pm 0.16$ & $0.88 \pm 0.18$ & $3.35 \pm 0.40$ & $9.81 \pm 1.20$ \\
Total $(\mathrm{M}+\mathrm{A})$ & $1.54 \pm 0.45$ & $1.15 \pm 0.27$ & $3.54 \pm 0.49$ & $10.38^{*} \pm 0.79$ \\
\hline T-0: beginning of surgical procedure & & & \\
T-F: end of surgical procedure & & & \\
T-12 $\mathrm{h} / \mathrm{T}-24 \mathrm{~h}: 12$ and 24 h p.o. \\
$* P<0001$ when compared to T-0
\end{tabular}

Glucose $(98.40 \pm 9.05$ versus $163.55 \pm 19.50)$ and pyruvate $(0.16$ \pm 0.22 versus $0.27 \pm 0.03$ ) concentrations were significantly increased 12 hours following completion of surgical procedure in comparison to
T- 0 . Pyruvate concentrations were significantly increased in patients submitted to arciform incisions 12 hours postoperatively compared to midline incision patients (Figures 1, 2).

Blood lactate and acetoacetate concentrations were similar in all groups. On the other hand, 3-hydroxybutirate $(0.21 \pm 0.04$ versus 0.14 \pm 0.04 - Figure 3$)$ and ketone bodies concentrations $(0.26 \pm 0.04$ versus $0.14 \pm 0.04$ - Figure 4$)$ were significantly decreased 24 hour later in comparison to $\mathrm{T}-0$.

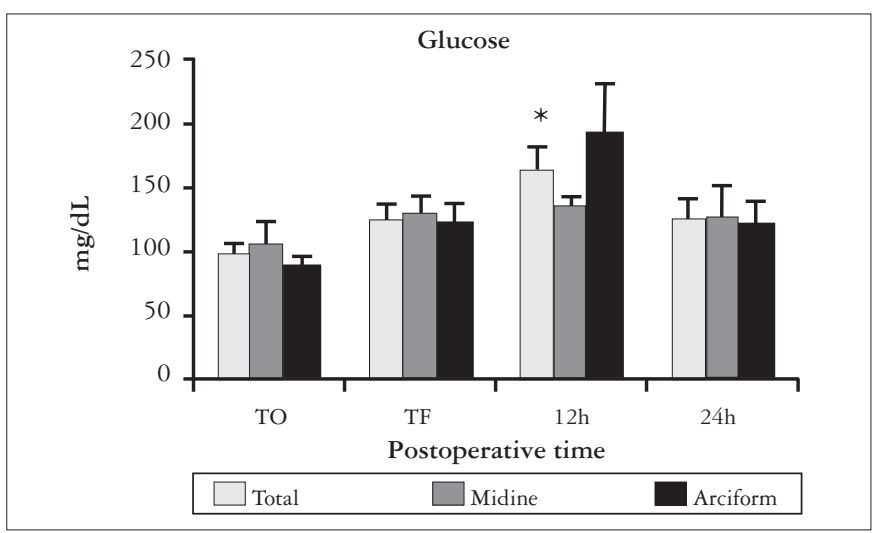

* $P<0.001$ compared to T.O
FIGURE 1 - Postoperative glucose concentrations according to type of incision and postoperative time

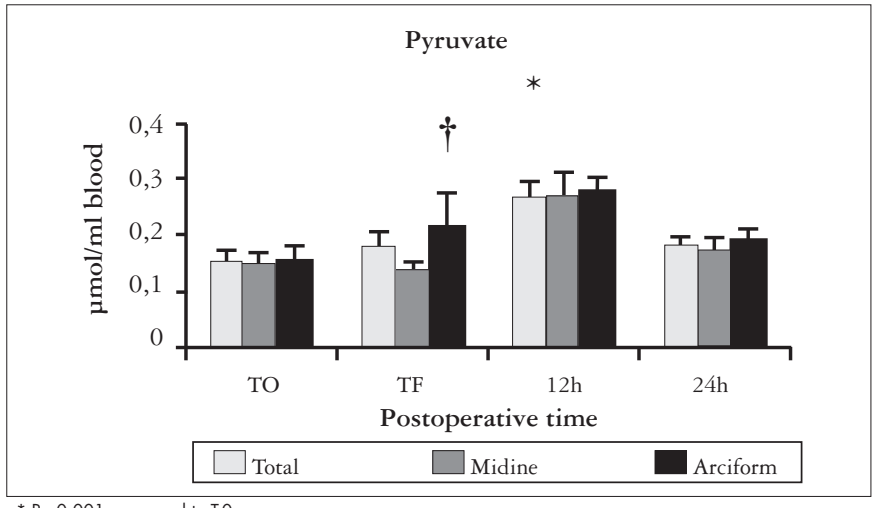

t $P<0.05$ compared to median access

FIGURE 2 - Postoperative pyruvate concentrations according to type of incision and postoperative time

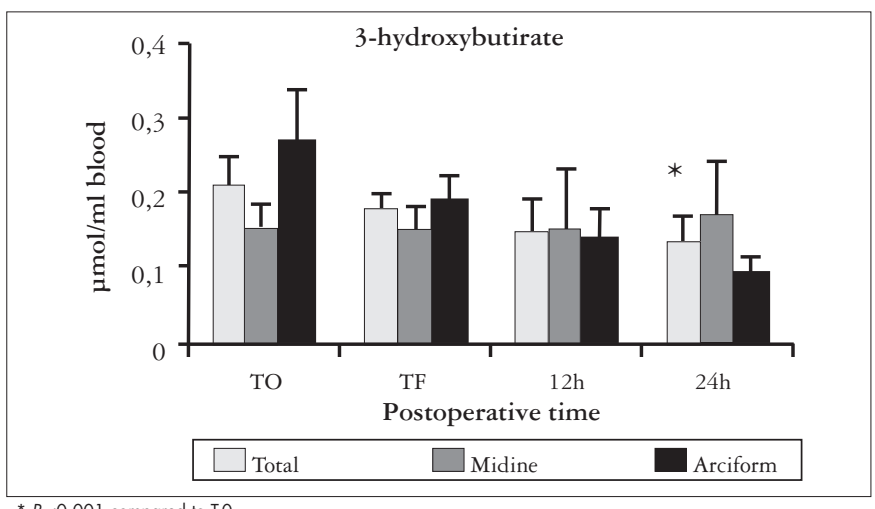

FIGURE 3 - Postoperative 3-hydroxybutirate concentrations according to type of incision and postoperative time 


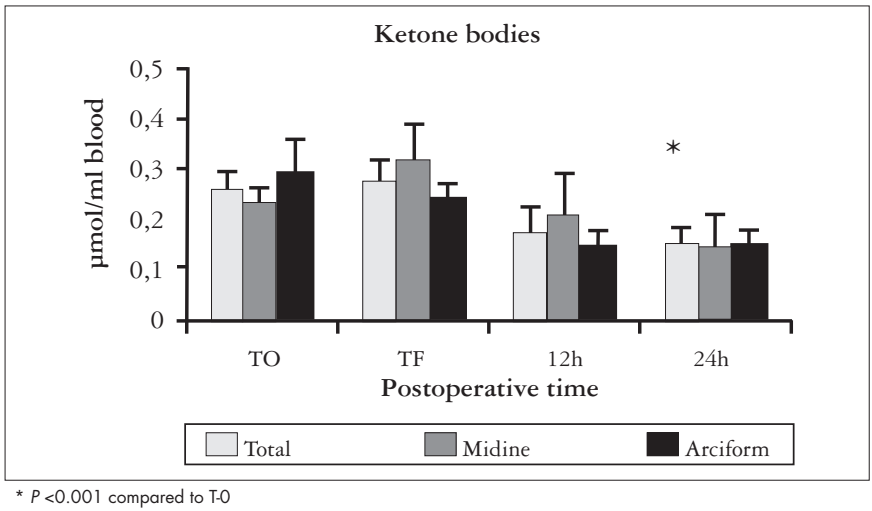

FIGURE 4 - Postoperative ketone bodies concentrations according to type of incision and postoperative time

\section{DISCUSSION}

The ideal abdominal incision should allow easy access to any area of the abdominal cavity, appropriate operative field for safe surgical maneuvers and minimal trauma to tissues, preserving neurovascular structures.

The explanation for decreased dieresis time and blood loss for midline incisions compared to arciform incisions rests on the anatomy. Midline incisions are of easier execution, there is less bleeding and if there is need for enlargement it can be carried out easily. Besides, the access to any organ of the abdominal cavity or retroperitoneal space is facilitated. On the other hand arciform incisions require muscle transection, resulting in greater blood loss and a longer period of time for its implementation.

The fall in hematocrit and hemoglobin levels in both groups may be explained by hemodilution secondary to venous hydration and trans-operative oliguria, with increase of plasma volume. Decrease in lymphocyte count in both groups during postoperative period is related to surgical trauma which may lead to immunosupression. BEZERRA ${ }^{(2)}$ in a comparative study (laparotomic versus laparoscopic procedures) in colorectal operations, reported the fall of leukocyte count in early operative time followed by significant elevation of the leukocyte count at the end of the operation, in both groups studied, concluding that the two methods alter inflammatory response.

Potassium concentrations in both midline and arciform incisions presented no statistical significance despite the fact that the trauma imposed by a transverse abdominal incision is known to be superior to that one observed in midline incisions. Muscle section and possible potassium liberation with rise in serum potassium would be expected, due to tissue lesion. In contrast to this expectation, a decrease in serum potassium was observed $24 \mathrm{~h}$ postoperatively as compared to T- 0 when all 20 patients were considered.

Albumin is responsible for the maintenance of plasma osmotic pressure and the transportation of small molecules. Protein catabolism (proteolysis) due to trauma supplies amino acids for the synthesis of protein and glucose. Increased glucose requirements secondary to trauma shift the metabolic pathway to gluconeogenesis, leading to accelerated albumin consumption (hypoalbuminemia) postoperatively ${ }^{(13)}$. Albumin is also a negative phase reactant protein and has its plasma concentration decreased following trauma due to decreased hepatic synthesis which is diverted to the production of other positive phase reactant proteins such as protein $\mathrm{C}$ reactive ${ }^{(8)}$. The fall in albumin concentrations at the end of the surgical procedure (T-F) may be explained by decreased hepatic synthesis during surgery.

Erythrocyte sedimentation rate (ESR) is not a good inflammatory indicator for surgical trauma, as it may be affected by many factors. Elevation of ESR is usually related to increase of CRP or leukocytosis ${ }^{(12)}$. The significant fall of erythrocyte sedimentation rate at the end of the surgical procedure followed by return to normal levels during the postoperative period might be related to its unspecific response to trauma.

Systemic inflammatory response to trauma causes increased production of acute phase proteins. CRP is an acute phase and it reaches its highest concentration within 24 hours as has occurred in the present study ${ }^{(4)}$.

Glucose concentrations were similar in both groups. Significant postoperative ( $\mathrm{T}-12 \mathrm{~h}$ ) increase in glucose concentration may be explained by increased liver glycogenolysis. This may be related to glucagon and epinephrine inhibition of insulin secretion and peripheral carbohydrate breakdown by growth hormone.

The significant Increase of blood pyruvate concentrations $12 \mathrm{~h}$ postoperatively suggests decreased utilization of this metabolite for energy production by peripheral tissues in the early postoperative period. The absence of alterations in lactacemia suggests that surgical trauma was mild as severe trauma is accompanied by increase in lactacemia due to activation of Cori Cycle ${ }^{(8)}$.

Ketone bodies (acetoacetate and 3-hydroxybutyrate) are important alternative sources of energy to glucose. They are formed by a specific hepatic biochemical pathway (ketogenesis). Acetyl CoA is the main substrate for their synthesis. Fasting alone leads to increased concentrations of ketone bodies (hyperketonemia) in the first 24-48 hours. However when fasting is accompanied by trauma the hyperketonemic response to fast fails to occur. The catabolic phase of trauma promotes, via interleukin-1, elevation of insulin which in turn leads to a fall in hepatic ketogenesis ${ }^{(4)}$. The significant decrease in ketone bodies concentrations measured at the end of 24 hours following the surgical procedure may be explained by failure of the hyperketonemic response to this fasting period related bariatric trauma.

\section{CONCLUSIONS}

Capella's gastroplasty induces metabolic and inflammatory changes in blood parameters, with significant fall of hematocrit, hemoglobin, potassium, albumin, 3-hydroxybutirate and ketone bodies along with significant elevation of erythrocyte sedimentation rate, C-reative protein, glucose and pyruvate concentrations.

There is no evidence of technical superiority of arciform over midline incision for tactical approach of the abdominal cavity for this bariatric procedure. 
Moura Jr LG, Guimarães SB, Castro-Filho HF, Machado HF, Feijó FC, Vasconcelos PRL. Gastroplastia de Capella: alterações dos metabólitos e proteínas de fase aguda comparando as vias de acesso mediana versus transversa arciforme. Arq Gastroenterol 2004;41(4):215-9.

RESUMO - Racional - A obesidade tem efeitos de saúde adversos e a reeducação dietética não proporciona perda de peso duradoura. Em pacientes adequadamente selecionados o tratamento cirúrgico pode ser benéfico. Objetivo - Avaliar a resposta metabólica pós-operatória precoce em pacientes submetidos a gastroplastia de Capella usando duas diferentes técnicas cirúrgicas de acesso à cavidade abdominal. Pacientes/Método - Vinte pacientes $(9$ homens e 11 mulheres, idades variando de 21 a 53 anos) foram aleatoriamente distribuídos antes da realização de uma das duas incisões de acesso cirúrgico (transversa arciforme ou mediana supra-umbilical). Amostras de sangue foram obtidas no princípio e no fim da operação, e no período pós-operatório, às 12 (T-12 h) e 24 horas (T-24 h). Foram avaliados os tempos de diérese e síntese, perda sangüínea, planimetria do campo operatório, duração da cirurgia, permanência hospitalar, hemoglobina, hematócrito, contagem de linfócitos, potássio, albumina, taxa de hemossedimentação, proteína C-reativa, glicose, piruvato, lactato e corpos cetônicos. Resultados - O tempo de diérese diminuiu significativamente no acesso mediano. Duração da cirurgia, permanência hospitalar, hematócrito, hemoglobina, contagem de linfócitos, concentrações de potássio e albumina foram semelhantes em ambos os grupos. Houve aumento significativo das concentrações de proteína C-reativa (T-12 h) e glicose e piruvato (T-24 h) depois da conclusão do procedimento cirúrgico. As concentrações de corpos cetônicos diminuíram significativamente 24 horas após o término da intervenção cirúrgica. Conclusão - A gastroplastia de Capella induz mudanças metabólicas e inflamatórias nos parâmetros hematológicos. Não há evidência da superioridade técnica do acesso cirúrgico arciforme comparado ao acesso mediano, neste estudo.

DESCRITORES - Obesidade mórbida, cirurgia. Obesidade mórbida, metabolismo. Gastroplastia.

\section{REFERENCES}

1. Albrecht RJ, Pories WJ. Surgical intervention for the severely obese. Baillieres Best Pract Res Clin Endocrinol Metab 1999;13:149-72.

2. Bezerra JB. Estudo clínico prospectivo sobre aspectos das respostas imunológica inflamatória e metabólica em pacientes portadores de doença colorretal, submetidos à operação laparotômica versus operação laparoscópica [dissertação] Fortaleza: Faculdade de Medicina da Universidade Federal do Ceará; 1998.

3. Capella JF, Capella RF. The weight reduction operation of choice: vertical banded gastroplasty or gastric bypass? Am J Surg 1996;171:74-9.

4. Figueiredo PHD, Vasconcelos PRL. Adaptative hiperketonemia upon intra venous infusion of lipid emulsions in fasted septic patient. Intensive Care Med 1998;24 (Suppl 1): S48.

5. Halpern A. Perspectivas futuras para o tratamento do obesidade. In: Halpern A, editor. Obesidade. São Paulo: Lemos Editorial; 1998. p.342-54.

6. Hohorst HJ. D-Glucose-6-phosphate and D-fructose-6-phosphate. Determination with glucose-6-phosphate dehydrogenase and phosphoglucose isomerase. In: Bergmeyer HU, editor. Methods of enzymatic analysis. New York: Verlag Chemie, Weinheim/ Academic Press; 1963. p.134-8.

7. Hohorst HJ, Kreutz FH, Bütcher TH. [On the metabolite content and the metabolite concentration in the liver of the rat]. Biochem Z 1959;332:18-46.
8. Kushner I. C-reative protein and the acute-phase response. Hosp Pract (Off Ed) 1990;25:13, 16, 21-8.

9. Livingston EH. Obesity and its surgical management. Am J Surg 2002;184:103-13.

10. Slein MW. Determination with hexokinase and glucose-6-phosphate dehydrogenase. In: Bergmeyer HU, editor. Methods of enzymatic analysis. New York: Verlag Chemie, Weinheim/Academic Press; 1963. p.117-23.

11. Trayhurn P, Beattie JH. Physiological role of adipose tissue: white adipose tissue act as an endocrine and secretory organ. Proc Nutr Soc 2001;60:329-39.

12. Unkila-Kallio L, Kallio MJ, Eskola J, Peltola H. Serum C-reative protein, erytrocyte sedimentation rate and white blood cell count in acute osteomyelitis of children. Pediatrics 1994;93:59-62.

13. Waitzberg DL. Nutrição enteral e parenteral na prática clínica. In: Cappini LZ, editor Obesidade. $2^{\text {a }}$ ed. Rio de Janeiro: Atheneu; 1998. p.402-6.

14. Williamson DH, Mellanby J, Krebs HA. Enzymic determinations of the D-(-) $\beta$ hydroxybutyric acid and acetoacetic acid in blood. Biochem J 1962;82:90-6.

Recebido em 26/9/2002 Reapresentado em 14/6/2004. Aprovado em 23/6/2004 